\title{
THE REPRESENTATIVES OF AMELANCHIER MEDIK. GENUS IN UKRAINE
}

\author{
Opalko Anatoliy Ivanovich
}

Ph.D. in Agriculture, Professor, Head of Department of Physiology, Genetics, Plant Breeding and Biotechnology, Sofiyivka National Dendrological Park of NAS of Ukraine opalko_a@ukr.net Kievskaya St., 12-a, 20300 Uman, Ukraine

\section{Andrienko Elena Dmitrievna}

Teacher, Department of Biology and Methods of Its Teaching, Uman State Pedagogical University named after Pavlo Tychyna olena_andrienko@ukr.net Sadovaya St., 2, 20300 Uman, Ukraine

\section{Opalko Olga Anatolyevna}

Ph.D. in Agriculture, Associate Professor, Senior Researcher, Department of Physiology, Genetics, Plant Breeding and Biotechnology, Sofiyivka National Dendrological Park of NAS of Ukraine opalko_a@ukr.net Kievskaya St., 12-a, 20300 Uman, Ukraine

\begin{abstract}
The information on fruit and decorative value, honey and medicinal properties of the genus Amelanchier Medik. is generalized. Their biological characteristics, chemical composition and palatability traits of the fruit, the ways of consumption and processing, including drying, preparing juices, syrups, jams, candied fruit jellies, confiture, and fruit wine are specified. The environmental adaptability and effectiveness of using juneberry for phytomelioration are mentioned. Several versions of the origin of the genus Amelanchier name and interpretation of its specific epithets are described. The controversial issues of the genus Amelanchier system were discussed from the classical and molecular genetic approaches. The attention is focused on two main aspects of views on the place of the genus Amelanchier representatives of the family Rosaceae Juss. within the particular subfamily, namely the subfamily Pyroideae Burnett (Maloideae S. Weber) or the subfamily Amygdaloideae Arn., which indicates the necessity for further comparative morphological and molecular genetic studies of the family Rosaceae. The directions of evolution, habitat and invasive ability of some species of the genus Amelanchier are characterised. The list of the genus Amelanchier representatives cultivated in Ukraine is given.
\end{abstract}

Key words: areal, biodiversity, number of chromosomes, DNA sequence, family, floristic region, juneberry, phytomeliorative, taxonomy, tribe. 


\section{Introduction}

Among the decisive premises of successful conservation of biotic diversity (biodiversity), and the enrichment of local diversity of any plant, including representatives of the genus Amelanchier Medik. under certain conditions, one should determine their systematic position, ascertainment of geographical origin and peculiarities of phylogenetical connections on the interfamily and interspecies levels. Such information will be favourable to scientifical planning of their introduction, prevention from invasion, and also create sources of outgoing material to conduct their breeding.

According to the classification of Armen Takhtadzhan [62], representatives of the genus Amelanchier (Juneberry) belong to the family Rosaceae, subfamily Pyroideae (former Maloideae), tribe Maleae.

In Ukraine, representatives of the genus Amelanchier are considered unconventional for growing, but interest in Juneberry and many other promising, but currently undervalued plants (mostly known to a narrow range of wildlife lovers) increases with increasing population welfare. First of all, it is referred to the species Hippophae L. (sea buckthorn), Lonicera L. (honeysuckle), Sorbus L. (mountain ash) and Viburnum L. (viburnum), which, now together with Juneberry, are gaining more popularity due to the decorativeness, and high taste, remedial, and dietic qualities of their fruits $[39 ; 44]$. Juneberry is a very flexible and unpretentious plant. In the culture, and as well as in the natural state, it grows in the form of a large shrub, sometimes a tree. It can be used as an ornamental, nectareous, phytoreclamative, and medicinal plant. It is valued as a fast-growing, fast-foetal, and perennial fruit crop. It has a number of other benefits. According to the degree of resistance to unfavourable conditions, Juneberry is a unique plant. It has a great tolerance to winter conditions. The plant itself is capable of withstanding temperatures of $40-50{ }^{\circ} \mathrm{C}$ below zero, and the flowers that blossomed - to minus $5-7{ }^{\circ} \mathrm{C}[3 ; 9 ; 39]$. Juneberry successfully grows on the soils of different mechanical makeups and acidity. It thrives on the rather moisty light soil, sometimes even on the marshy ones. At the same time, it withstands drought well and can grow on rocky and sandy dry areas. However, it can't withstand poorly drained clay soils with low humus content $[9 ; 39]$. Juneberry is a photophilous plant, but it can grow in the shade. A.D. Burmistrov mentions an interesting biological feature of young Juneberry plants (under 5 years), that it has an ability to withstand relatively intense shading [9]. Juneberry plants are distinguished by being sufficiently fast growing and by the age of ten they reach their full development. Duration of the yielding period for the bush is 60-70 years (some shoots can grow up to 15 years) $[5 ; 9]$.

Juneberry is a hermaphrodite plant, outcrossing (self-fertilizes rarely). The Juneberry can berry on last years' shoots even if it had a single area that was self-fertilized $[3 ; 9 ; 44]$. It starts to berry rather early; it produces crops in 3-4 years. It is characterized by annual and abundant berrying which reaches $3-5 \mathrm{~kg}$ from wildgrowing bushes of 5 years, and up to $10-12 \mathrm{~kg}$ from 10 or more year-old ones $[3 ; 9]$.

A positive feature of Juneberry is that it is rarely affected by diseases. Sometimes, there can be powdery mildew, fruit rot, leaf blight, and leaf rust. However, many pests willingly settle on it. Among them are: the green apple aphid (Aphis pomi Deg.), the apple blossom weevil (Anthonomus pomorum L.), the garden chafer (Phyllopertha horticola L.), caterpillars of different species of butterflies (Operophtera brumata L., Euproctis chrysorrhoe L., Orgyia antiqua L., Dasychira pudibunda L., Acronicta tridens (Den. \& Schiff.), Melanchra persicariae L.), leaf-rolling moths of the genus Pandemis and others. Forming the complex of phytophages of this genus takes place mainly due to broad polyphages and olygophages connected primarily with apples, hawthorns and some other representatives of Maleae [5; 34; 53]. Besides, sparrows, thrushes, and robins like juneberries, so it is sometimes necessary to scare these birds to preserve the harvest $[5 ; 34]$.

Juneberries are sweet, exquisitely tender, and very useful. Their sugar content is $8-12 \%$ with a prevalence of fructose and glucose; organic acids 0.4-0.7 (preferably apple); tannins and dyes $0.5-0.8 ; 1.5-2.5 \%$ of pectin; $0.4-0.7 \mathrm{mg} / 100 \mathrm{~g}$ of carotene; $35-45$ of vitamin $\mathrm{C}$, from 7 to $12 \mathrm{mg} /$ $100 \mathrm{~g}$ of vitamin $\mathrm{B} 2,0.2-1.0 \mathrm{mg} / 100 \mathrm{~g}$ of provitamin $\mathrm{A}$; to $100 \mathrm{mg} / 100 \mathrm{~g}$ to anthocyanins; among these trace constituents, there is also copper, lead, and 
cobalt. Beta-sitosterol can also be found in them. It is a substance that helps to reduce cholesterol, and coumarins, which are characterized by an antisclerotic effect $[3 ; 36 ; 39]$. Its fruit - in the fresh, dried, frozen, and processed form - is consumed. Juice, syrup, wine, liqueur, jam, confiture, jelly, and marmalade can be prepared. While processing juneberries, other berries (for example, black currant) can be mixed together, but only 300 grams of sugar per $1 \mathrm{~kg}$ of fruit is used (due to the high sugar content of juneberries). A peculiarity of freshly picked juneberries is the fact that they are very difficult to squeeze juice from, but if they are left for about a week, then $70 \%$ of juice, from the total mass, accumulates in them [5].

The value of the Juneberry fruit as a fine, raw material for producing fruit wines was first emphasized by the academician V.V. Pashkevych who initiated introducing juneberry into the Ukrainian culture. It was V.V. Pashkevych who launched its plantation while establishing an arboretum in the territory of modern NDP "Sofiyivka" NAS of Ukraine, now known as Pashkevich Arboretum [9; 32]. The fruit of Juneberry dries quickly in the bright sun, as well as, in the home dryers and, by its appearance, are similar to raisins - dried berries of seedless grape cultivars. Fruits that have just ripened contain more vitamin $\mathrm{C}$ and are better for freezing and conservation; completely ripe fruits contain more sugar and can be used to make juice and wine. While cooking wine, the juice is fermented without adding sugar. The wine has a pleasing savour, nice dark-ruby color, and its strength is $8-10^{\circ}[5]$.

Juneberry, as a fruit crop, is grown on the industrial scale in the USA and Canada. Accordingly, much attention is paid to the breeding work. There are cultivars grown for fruit: 'Beaverlodge', 'Bluff', 'Buffalo', 'Elizabeth', 'Idaho Giant', 'JB30', 'Killarney', 'Lee № 3', 'Moonlake', 'Sturgeon', 'Thiessen', 'Thiessen RS', 'Timm' and so on, and also cultivars, which combine its high productivity and quality with decorative value: 'Altaglow', 'Gypsy', 'Honeywood', 'Martin', 'Nelson', 'Northline', 'Parkhill', 'Pembina', 'Regent', 'Smoky', 'Success' and so on. There are purely ornamental cultivars: 'Altaglow', 'Autumn Brilliance', 'Autumn Sunset', 'Ballerina', 'Carleton', 'Cumulus', 'Fergi', 'Forest Prince', 'Helvetia', 'Hollandia', 'Jennybelle', 'Lustre', 'Prince
Charles', 'Prince William', 'Princess Diana', 'Rainbow Pillar', 'Reflection', 'Robin Hill', 'Silver Fountain', 'Tradition', 'White Pillar', etc. Among them there are representatives of the different species: A. alnifolia, A. bartramiana, A. canadensis, A. laevis, A. spicata, A. stolonifera, and a number of interspecies and hybrids between other species $[5 ; 33 ; 71]$.

Juneberry, as an ornamental plant, is suitable for the arboretums, dendrological parks, and settlement gardening. It is possible to form alleys, delicate hedges (well-tolerated to a cut), Juneberry is effective in group plantings and solitaires. It gives off a pleasing effect when placed in the background of other plants or along buildings. At the same time, due to the abundant frondescence, blossoming and fruiting Juneberry plants are ornamental throughout the year. In spring, at the time of blossoming, its inflorescences are light and delicate against the background of the young leaves, and its white and cream-coloured flowers have a light pleasant scent. In early summer, because it is still ripening, the fruit is first green. Then, on the one side of the little fruit, there is a pink erubescence and the ripe fruit is usually blue and purple, but the color can vary from cream to almost black. The juneberries' leaves display a special decorativeness throughout the growing season: when blooming, they are whitetomentose, later - green, green-gray, green-red, in autumn - yellow, orange, red, purple. In winter Juneberry shoots can be graphically distinguished above the snow cover $[5 ; 9 ; 71]$.

During blossoming, Juneberry is eagerly visited by bees; providing them with an early spring honey gathering (lots of pollen and little nectar) and in gardens it attracts them to other fruit crops, thus increasing their productivity $[24 ; 25 ; 56]$.

Juneberry is used for fixing gullies and eroded slopes. While phytomelioration of recreational and devastated forest areas, it can even be used as an attractive factor for forming forest environment [25; 57]. It is recommended that Juneberry be planted in multifunctional shelter belts, namely in forest shelter and snow shelter belts along railways or highways. It can also be planted in different rows and tiers of windbelts as an orchard-protecting belt that would protect field crops from winds - both dry and hot, as well as, help capture snow and use 
its meltwater better. Under its protection, currants, gooseberries, raspberries, strawberries, and others can be grown, while simultaneously being capable of capturing snow. If fruit crops need protection from the winter cold, the location in areas that are blown by the wind does not matter for Juneberry (due to its high degree of frost hardiness). Besides, heavy beds of Juneberry as orchard-protecting belts are a great place for nesting insectivorous birds $[3 ; 5 ; 9 ; 52]$. In addition, according to A.D. Burmistrov, the offer to plant Juneberry on the edge of the garden is not devoid of practical sense. During the Juneberry fruiting, which lasts about a month, its non-simultaneous ripening coincides with the time of fruiting strawberries, black currants, and sometimes, cherries. Because of this, attacks from birds (starlings, blackbirds) on these baseline fruit cultures are strongly reduced [9].

Juneberry wood is solid and resilient; with gray, reddish or reddish-brown color with slightly visible beams and annual rings. It has a silky surface, it can be easily bent and polished. It doesn't have a timber industry value because of the small diameter. In the past Juneberry wood was used for making ramrods and canes. It is perfectly suited for wickerwork, industrial and domestic and art objects, delicate holders for climbing plants can be made of it $[25 ; 38 ; 43]$.

Juneberry fruits are used with the purpose of treatment for atherosclerosis (due to the content of beta-sitosterol, which is an antagonist of cholesterol); for different diseases of the gastrointestinal tract (as an astringent); for the prevention of hypo-and avitaminosis $\mathrm{C}$ and $\mathrm{B}$ (as multivitamin remedy). Tincture of Juneberry flowers is used as antihypertensive and cardiotonic remedy. Decoction of the rind and leaves has astringent and coating properties and is used for the prevention of gastrointestinal diseases and for septic wounds epulosis $[36 ; 52]$.

A synonymous name for Juneberry was given to name to the City of Saskatoon - the largest in the Canadian province of Saskatchewan. It is derived from "mis-sask-quah-toomina", which is how the aboriginal inhabitants called the most wide-spread, local berries [58]. The importance of plants is proved by the fact that the Indian tribes distinguished between 8 individual species based on morphological differences in the plants. Juneberry flowers and fruits were used in ceremonial rites, and the beginning of harvest was celebrated by solemn feasts. Some tribes believed that even the first humans were created from Juneberry bushes [58].

Juneberry was widely used in the everyday life of the aboriginal inhabitants, and subsequently of the first settlers. Fruits were one of the staple foods, and often the only kind of fruit in sufficient quantity. They were consumed fresh, cooked, and dried. They were part of the ethnic dishes pemmican. Young cut shoots, dried fruits, and leaves were used for making drinks and treatment remedies for children, adults, and animals. Arrows and household tools were made from Juneberry solid wood [58].

The value of the genus Amelanchier representatives and some problems concerning their classification, especially their place in the family, led to an active search for phylogenetic connections between cultivated species and close families.

\section{Materials and Methodology}

Considering the importance of the problem of the starting material for breeding and taking into account the data obtained from the analysis of experimental and theoretical studies performed in different countries over a long historical period by scientists from different scientific schools [1; $3 ; 4 ; 10 ; 21 ; 29-31 ; 33 ; 37 ; 40-41 ; 50 ; 58 ; 62 ; 65$; $67-68 ; 71]$, the attempt to generalize available information is made. In this study the quota sampling method was used, which allowed to eliminate dubious publications using the criteria in peer-reviewed publication citing and giving priority to research that is carried out by international programs. Works on the domestication of the genus Amelanchier and their nearest families published in different years, were analyzed, summarized $[1 ; 10 ; 16-17 ; 20-22 ; 28 ; 36 ; 44 ; 48-$ $51 ; 58 ; 68-67 ; 71]$ and supplemented with the results of our study in the preparing process of the article.

\section{Results and discussion}

The origin of the genus name Amelanchier and etnobotanichni aspects of the species epithets. Genus Amelanchier Medik. (Juneberry) was described in 1789 by 


\section{БИОЛОГИЯ И БИОТЕХНОЛОГИЯ}

Friedrich Casimir Medicus [41], a German botanist and physician, director of the botanical garden in Mannheim. One of the first records about the plant dates back to the year 1581 [40]. However, before singling out Amelanchier as a separate genus (probably due to the similarity of its morphological features) Joseph Pitton de Tournefort reffered its species to the genus Mespilus [65] and Carl Linnaeus - to the genus Chionanthus [37].

The origin of the international name genus Amelanchier have several versions that are associated with taste or size of the fruit. According to one that is presented in a botanical dictionary by M.I. Annenkov edited in 1878 [4], the name Amelanchier is derived from the Greek words melea - apple and anchein - astringe, due to the astringent flavor of the fruit. According to another version, A.I. Poyarkova, while describing the genus in the flora of the USSR, associates the name with Provencal amelanche, which indicates the honey taste of the fruit [21].

The version proved by M.N. Caden and N.M. Terentyeva also explains the origin of the plant name from the Provencal amelanche, but as a fruit name of only one type of Juneberry, such as Amelanchier vulgaris Moench. Referring to a number of sources, they suggest a Celtic origin of the word Amelanchier [30]. Besides, the genus Amelanchier species are characterized by a large number of epithets that indicate their popularity and are usually associated with morphological features, habitat characteristics, fruit taste, etc. Thus, among the common American names of Juneberry species, G.N. Jones names: serviceberry, sarviceberry, sarvis, maycherry, june-berry, shadblow, shadbush, shadberry, shadblossom, shadflower, shad-wood, sugar pear, wild pear, lancewood, boxwood, Canadian medlar [29]. Attention is drawn to ethnobotanical and symbolic aspects of the genus Amelanchier application by indigenous peoples of North America, emphasizing the value of the plant. G. N. Jones gives an interesting interpretation of certain species epithets of American Juneberry species by associating them with the botanical characteristics and value of the plant for the indigenous population. Thus, the name Juneberry is stipulated by ripening fruit in early summer (from the month name June); in the eastern United States the names shadblow, shadberry, shadblossom, shadflower and shadwood are stipulated by the period of blossoming plants in early spring, which is an indicator of the breeding beginning of the shad run (river herring), which begins spawning migration from oceanic salt into fresh water rivers; the names lancewood and boxwood are stipulated by the use of dense wood as a part of tools (handle) [29].

According to the botanical dictionary by M.I. Annenkov [4], the genus Juneberry is called in Polish - Swidośliwka, in Czech - Muchownik, in Serbian - Graљac, Irga, in German - Fluhbirne, Beermispel, Felsenbirnbaum, in French Amelanchier, in English - The Medlar. The dictionary of Ukrainian scientific and vernacular names of vascular plants compiled by Yuri Kobiv [31] suggests names - sadova irha and irha.

The systematic position of the genus Amelanchier. The genus Amelanchier in classical phylogenetic, as well as in the molecular phylogenetic (cladistic) classification system of plants, is defined as a component of the family Rosaceae Juss. of the range Rosales Bercht. et J. Presl. [6;13; 19; 62]. The family Rosaceae is quite a large family of angiosperms, comprising about $90-110$ genera and $2000-4828$ species [13; $19 ; 23 ; 59 ; 64 ; 72]$, which averages about 100 genera and 3000 species [49].

Numerous "microspecies" are distinguished in many genera of Rosaceae, morphological differences between which are slight (for example, details of pubescence), but they are considered stable. Microspecies appear in groups where free interbreeding in populations is limited because of apomixis spread or other reasons. Therefore, if counting microspecies, the number of Rosaceae species can significantly increase [59].

Traditionally, on the basis of differences, mainly in fruit morphology and in basic chromosome numbers, the family Rosaceae were separated into 4 subfamilies: Spiraeoideae (Meadowsweet) - fruit - hose, rarely capsule, basic chromosome numbers 8 and 9; Rosoideae (Rose) - coccus, aggregate fruit, aggregateaccessory fruit, the hypanthium often takes part in the fruit formation, basic chromosome numbers 7, 9, rarely 8; Maloideae (Apple) - fruit - apple, basic chromosome number 17; Prunoideae (Plum) - fruit: drupe, basic chromosome number $8[23 ; 72]$. Other authors, depending on the 
occurrence of stipules, calyx structure, hypanthium, gynoecium, fruit, and other signs in the family Rosaceae distinguish from 3 to 12 subfamilies [13].

The genus Amelanchier, since the times of Adolf Engler (1903) [19], was defined within the subfamily Pomoideae (later Maloideae):

Division - Embryophyta siphonogama

Subdivision - Angiospermae

Classis - Dicotyledoneae

Subclassis - Archichlamydeae

Ordo - Rosales

Subordo - Rosineae

Familia - Rosaceae

Subfamilia - Pomoideae

Genus - Amelanchier.

Formed at the beginning of the last century [51], synopsis of the genera of the subfamily Maloideae as a part of the family Rosaceae with certain deviations [68] in his near-classical state is supported by many authors $[1 ; 28 ; 45$; 48] (Fig. 1).
However, more evidences are provided concerning the revision of the family Rosaceae appropriateness on regrouping subfamilies, supertribes, tribes, subtribes, some genera and species with the simultaneous elimination of the subfamily Maloideae [10; 16; 46; 49].

The revision of the family Rosaceae was supported by Armen Takhtajan, who suggested a new version of flowering plants system, revised according to the latest results of molecular phylogenetics in the book "Flowering Plants" reissued in 2009 [62]. Armen Takhtajan highlights subfamily Pyroideae (formerly Maloideae) in the family Rosaceae, combining in it 27 genera in four tribes, defining the genus Amelanchier among the families of the tribe Maleae (Tab. 1):

Accordingly, the systematic position of the genus Amelanchier, according to Armen Takhtayan's system [62], appears as follows:
Divisio - Magnoliophyta
Classis - Magnoliopsida (Dicotyledons)
Subclass - Rosidae

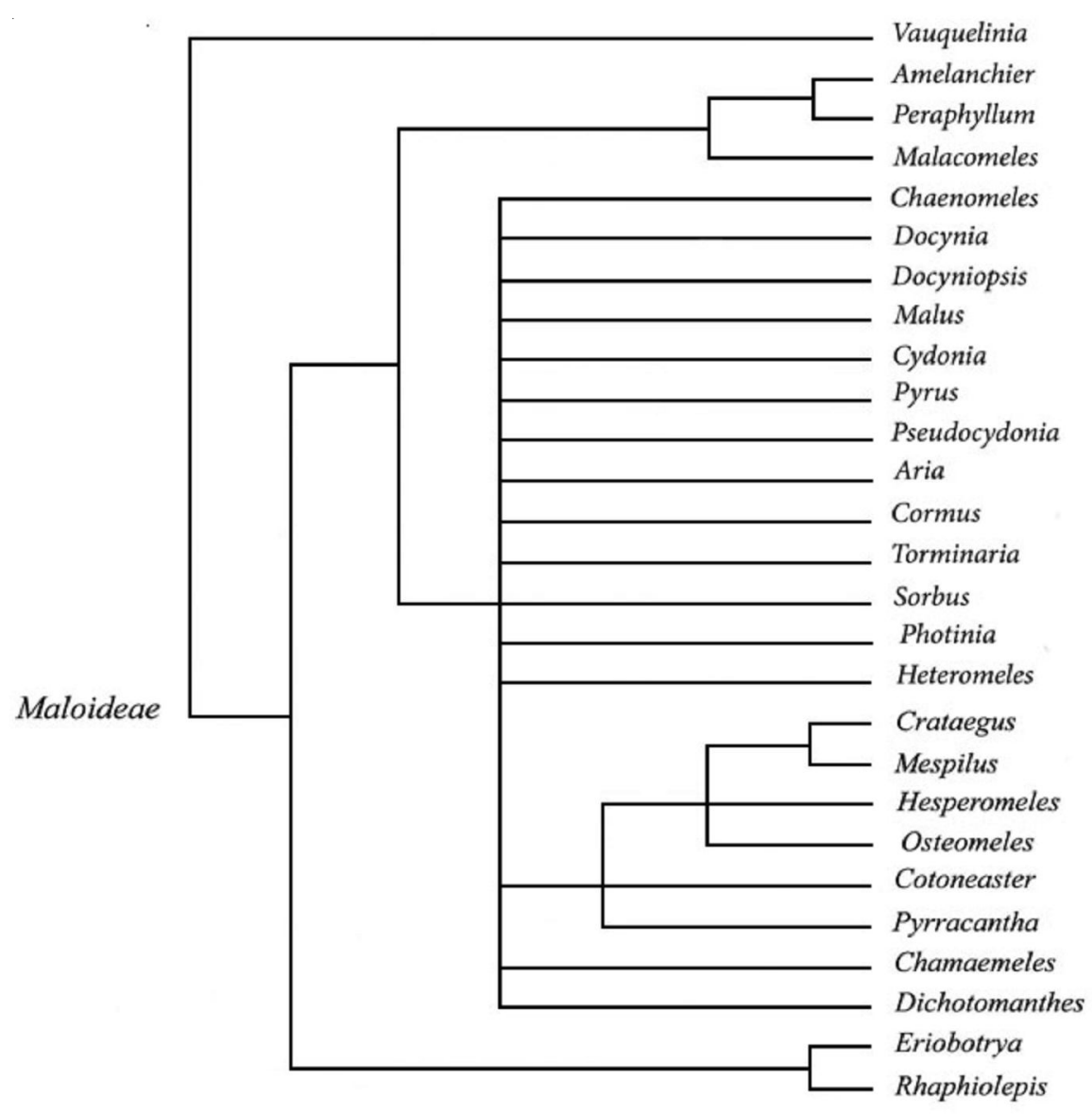

Fig. 1. Simplified cladogram of the subfamily Maloideae (according to Aldasoro J.J. et al., 2005 [1] as amended [46]) 


\section{БИОЛОГИЯ И БИОТЕХНОЛОГИЯ}

Superordo - Rosanae

Ordo - Rosales

Familia - Rosaceae

Subfamilia - Pyroideae (Maloideae)

Tribus - Maleae

Genus - Amelanchier.

According to the analysis of subfamilies from the family Rosaceae, performed by a group of scholars of different universities in the USA, Canada and Sweden after six nuclear (18S, gbssi1, gbssi2, ITS, pgip, ppo) and four chloroplastic (matK, ndhF, rbcL, and trnL-trnF) segments of DNA sequences $[10 ; 16 ; 49]$, only the subfamily Rosoideae (Juss.) Arn. turned out monophyletic, with the basic chromosome number $x=7$ or 8 , except for the tribe Dryadeae $(x=9)$. Instead, the subfamilies Prunoideae and Maloideae in the traditional sense were paraphyletic, and Spiraeoideae - polyphyletic group. On this basis, the rank of the first two subfamilies is proposed to reduce to the tribe and together with the other related tribes to combine into one monophyletic (in a very broad sense) subfamily Spiraeoideae C. Agardh, with $x=8,9,15$ or 17 . Therefore, the supertribe Pyrodae Camp., Ev., Morg. et Dick. with the tribe Pyreae Baill. were included to the subfamily Spiraeoideae ( $x=17$, with the exception of the genus Vauquelinia Correa ex Humb. Et Bonpl. with $x=15$ ), the subtribe of which Pyrinae absorbed most of the genera of the subfamily Maloideae, including the genus Amelanchier. This extension of the subfamily Spiraeoideae enabled us to determine the systematic position of the genus Amelanchier within the family Rosaceae as follows [10; 46-47]:

Familia - Rosaceae Juss.

Subfamilia - Spiraeoideae C. Agardh

Supertribus - Pyrodae Camp., Ev., Morg. et Dick.
Tribus - Pyreae Baill.

Subtribus - Pyrinae Dumort.

Genus - Amelanchier Medik.

However, there appeared to be a need to change the name of the subfamily Spiraeoideae due to the inclusion of the former subfamily Amygdaloideae to the newly formed subfamily Spiraeoideae. The fact is that under the International Code of Nomenclature for algae, fungi, and plants updated in 2011 [27] the taxon names must correspond to the earliest published name. Therefore, the priority name for the subfamily, which combines Spiraeoideae, Maloideae and Amygdaloideae is the name Amygdaloideae; for the tribe Pyreae - name Maleae Small; for the subtribe Pyrinae - name Malinae Rev. (Article 19.5, ex. 5).

While comparing the systematic position of the genus Amelanchier Medik., according to the different classification systems of plants different in time of creation and research level, the change in view on genus' phylogenetic connections can be partially traced (Tab. 2).

Herewith, the relative stability of the genus Amelanchier positiom within the major taxa of higher ranks should be noted. The range of fluctuations in the number of accepted species within the genus Amelanchier is quite wide: from 6 to $33[35 ; 48]$, and with infraspecific taxa to 37 [64]. The number of Latin species names used by different authors is nearly ten times as much. Most of these names, which are now considered to be unresolved, have: unplaced and unassessed names, synonyms [64], provisionally accepted names, infraspecific taxa [12], interspecific hybrids, or misapplied names.

A complex taxonomy of the genus is explained by morphological variation features of vegetative and generative organs, a large number

Table 1

The synopsis of the Pyroideae genera (formerly Maloideae) by Armen Takhtayan (2009) [62]

\begin{tabular}{|l|l|}
\hline \multicolumn{1}{|c|}{ Tribus } & \multicolumn{1}{|c|}{ Genus } \\
\hline Kageneckieae & Kageneckia \\
\hline Lindleyieae & Vauquelinia; Lindleya \\
\hline Maleae & Photinia (у тому числі Stranvaesia); Heteromeles; \\
& Eriobotrya; Rhaphiolepis; Sorbus; Chamaemespilus; Aronia; \\
& Amelanchier; Pyrus; Malus; Eriolobus; Peraphyllum; \\
& Docynia; Cydonia; Pseudocydonia; Chaenomeles \\
\hline Crataegeae & Cotoneaster; Malacomeles; Chamaemeles; Pyracantha; \\
& Crataegus; Mespilus; Hesperomeles; Osteomeles \\
\hline
\end{tabular}


The systematic position of the genus Amelanchier Medik. according to different plant classification systems

\begin{tabular}{|l|c|c|c|}
\hline \multirow{2}{*}{ Taxon } & \multicolumn{3}{|c|}{ Classification systems of plants } \\
\cline { 2 - 4 } Division & Engler, 1903 [19] & Takhtajan,2009 [62] & APG III (2009) [26-27] \\
\hline Subdivision & $\begin{array}{c}\text { Embryophyta } \\
\text { siphonogama }\end{array}$ & Magnoliophyta & - \\
\hline Classis & Angiospermae & - & - \\
\hline Subclassis & Dicotyledoneae & $\begin{array}{c}\text { Magnoliopsida } \\
\text { (Dicotyledons) }\end{array}$ & - \\
\hline Superordo & Archichlamydeae & Rosidae & - \\
\hline Ordo & - & Rosanae & - \\
\hline Subordo & Rosales & Rosales & Rosales \\
\hline Familia & Rosineae & - & Rosaceae \\
\hline Subfamilia & Pomoceae & Rosaceae & Amygdaloideae \\
\hline Tribus & - & Pyroideae (Maloideae) & Maleae \\
\hline Subtribus & - & Maleae & Malinae \\
\hline Genus & Amelanchier & Amelanchier & Amelanchier \\
\hline
\end{tabular}

of divergent and intermediate forms, polyploidy, hybridization, and a tendency to apomixis, causing the so-called occurring of agamospecies [11] and determining some taxonomic difficulties.

Generalized data on the genus Amelanchier taxonomy combine 279 names (including infraspecific). Of these 243 scientific plant names of species, $28(11.5 \%)$ are accepted species names, 93 (38.3\%) unassessed names, and 122 $(50.2 \%)$ are synonyms [64].

We can assume that the ancestors of the genus Amelanchier modern species emerged by the end of the Cretaceous period of the Mesozoic era, or the beginning of the Paleogene period of the Cenozoic era, when there was a relatively rapid modernization of the flowering plants genus structure. So in the Eocene floras, most species can be classified within contemporary families. So, it is quite natural that certain fossilized footprints of Amelanchier are found in western North America, namely in the deposits of the Eocene period (48-50 million years ago) [69]. During the Neogene, in the arid regions of North America, a kind of "Madro-Tertiary" flora was formed, a detailed study of which [7] showed genus Amelanchier among other typical representatives of the fossil flora.

Evolution directions of the genus Amelanchier. Adaptive radiation and hybridization are distinguished among the determinative evolution directions of the genus [10]. Thus, adaptive radiation most likely is caused by the formation of fleshy fruit and is related to vital functions of animals.

The conception about the growing importance of endozoochory during the process of fouling symphycarpous fruit aggregating by floral tube (apples formation), is also supported by Armen Takhtajan [60].

In general, the hypothesis about the origin of the subfamily Pyroideae (formerly Maloideae) shows the connection of this group with common ancestors of the most ancient subfamily Spiroideae. At the same time, they are close to Rosoideae according to the type of fruit-apples structure, as well as Prunoideae, as woody plants have a similar leaf shape, type of inflorescence, and structure of sepals and petals [23]. It should also be mentioned that the representatives of Pyroideae (Maloideae) have a basic chromosome number $x=17$ [54-55].

Most of the other representatives of the Rosaceae family are characterized by a much lower number of chromosomes $x=7,8$, or 9 . That's why the logical assumption about the polyploid origin of chromosome number Pyroideae (Maloideae) was made. According to C.D. Darlington and A.A. Moffett (1930), Pyroideae (Maloideae) appeared from Rosoideae and is a triple trisomic tetraploid $(x=7+7+3=17)$. In other words, it would double the number of chromosomes (all seven) with the addition of one more chromosome from three different pairs in one of the ancient specimens of Rosaceae with haploid 
set $\mathrm{x}=7$ (very common chromosome number in the family Rosaceae) [15; 46]. However, the probability of triple trisomy is significantly lower than of amphidiploidy, so more followers supported the hypothesis of K. Sax (1931), who believed that Pyroideae (Maloideae) are alloploids arising out of doubling the number of chromosomes in hybrids between distant ancestors of two distant generic types. According to his view, this could be representatives of the subfamilies Prunoideae, which has a basic chromosome number $x=8$ and Spiroideae - with $x=9$, the uniting of which has put modern Pyroideae (Maloideae) $x=17$ chromosomes in a common genome [46; 54].

In those times, quoting G.L. Stebbins (1950), Armen Takhtajan [60] expressed an opinion that taking into account the data of karyology and morphology of the flower, the most probable explanation for the origin of Pyroideae (Maloideae) is based on the fact that Pyroideae (Maloideae) is diploidizated polyploid arising out as a result of an ancient hybridization between Spiroideae and Rosoideae, which explains the basic haploid number of this subfamily $x=17$.

The fact of mainly bivalent chromosomes conjugation of Pyroideae (Maloideae) [54] gives ground to define the representatives of this subfamily as functional diploids. Although one can find tetraploid (68 chromosome) species (including the genus Amelanchier) near the diploid $2 n=34$ in the subfamily $[46 ; 55 ; 72]$, the proportion of functional diploids in Pyroideae (Maloideae) prevails, and it is much larger than in other subfamilies of Rosaceae [17].

The results of the research released at the beginning of the 21 st century, which were carried out at comparing the DNA sequences of the subfamily Pyroideae (Maloideae) and a large number of other representatives of the family Rosaceae, shake the prestige of these hypotheses $[10 ; 16 ; 49]$. The analysis of the obtained materials on the genomes similarity of the subfamily Pyroideae (Maloideae) specimens and the genus Gillenia from the subfamily Spiraeoideae, gave good reasons to believe that probably the genus Gillenia is the closest relative to the apple. All nuclear and chloroplast cladograms show that the genus Gillenia is invariably manifested as a sister group to Pyroideae (Maloideae). Taking into consideration that Gillenia has a less number of chromosomes $(x=9)$ than all Pyroideae
(Maloideae) $(x=17)$, the authors assumed that the genom of Pyroideae (Maloideae) was formed monophyletic as a result of autopolyploidy of the genus Gillenia representatives from $x=9$ to $x=18$ and subsequent aneuploidy (nullisomy) to the current number of chromosomes $x=17$. Thus, the basic chromosome number $x=17$ is common to all Pyroideae (Maloideae) and some Spiraeoideae (Kageneckia and Lindleya), although Vauquelinia representatives have $x=15$, which may become a reason of a system revision [20].

Flow cytometry data [63] also showed the similarity of the genomes Pyroideae (Maloideae) and Gillenia. The comparative analysis of the characteristics of female and male gametophytes Gillenia and seven genera representatives of the subfamily (Chaenomeles, Cotoneaster, Crataegus, Mespilus, Photinia, Rhaphiolepis and Sorbus) confirmed the similarity of Pyroideae (Maloideae) and Gillenia floral development [22].

Admitting evidences of monophyletic nullisomic origin of the subfamily Pyroideae (Maloideae) representatives one has to explain the facts of mainly bivalent conjugation of their chromosomes by a prolonged evolution, in the process of which during interspecies hybridization and polyploidization within common ancestral group with Gillenia took place. Such course of events is more likely than the gradual formation of a functional diploid from an autoaneuploid that perhaps arose out of an autotetraploid because of its nullisomy. These assumptions were confirmed as a result of summarizing data of collinearity (the order of location) analysis of genes along each of the 17 chromosomes of the apple. Working according to a united international program, 86 scientists from Italy, France, New Zealand, Belgium and the United States have examined the chromosomes of the genome sequence of the apple 'Golden Delicious' [67].

They showed similar collinearities between large segments of chromosomes 3 and 11, 5 and 10,9 and 17, 13 and 16, and between short segments of chromosomes 1 and 7,2 and 7,2 and 15, 4 and 12, 12 and 14, 6 and 14, 8 and 15, about which they reported in a joint publication. They found that relatively not long ago, less than 50 (approximately 30-45) million years ago, there was a spontaneous duplication (autoreduplication) 
of the 9 chromosome ancestor genome of the apple with subsequent loss of the eighteenth chromosome and forming 17 chromosome karyotype of modern apples (Fig. 2).

Herewith, the first chromosome of the apple ancestor donated genetic material to 5 and 10 chromosomes of apple trees, respectively 3 and 11 chromosomes intergraded from the second chromosome, 9 and 17 - from the third one, 13 and 16 - from the fourth one, and 4, 6, 12 and 14 chromosomes of apples are combined from the fragments of the fifth and sixth ones. The first and the second chromosomes are developed from the fragments of the seventh and ninth ancestors of the apples and from the seventh chromosome seventh one respectively. The origin of 8 and 15 chromosomes of apples is a little more complicated. If the eighth chromosome of apples contains sequences of the eighth apple ancestor chromosome, then 15 consists of fragments of the eighth and ninth ones. But there is a reason to believe that the translocation of genetic material of the ninth chromosome took place before the above mentioned nullisomy (loss of the18th pair of chromosomes) [67].
It is assumed an existence (currently unidentified) of the gene regulator of conjugation of homologous chromosomes apple with functions similar to the display of the gene Phl, which governs the on-goings of wheat chromosomes during meiosis, preventing from multivalent conjugation of partially homologous chromosomes poliploids. It provided mainly bivalent conjugation (pairs) and the formation of functional diploids from the ancestral autotetraploid.

The areal of the genus Amelanchier. The genus Amelanchier representatives grow mainly in the forested areas of the moderate zone in the Northern Hemisphere mostly in light woodland slopes, light forests to an altitude of 1900 m above the sea level, and grow well on a variety of soils [50]. The areal of the genus Amelanchier is quite wide; it occupies the extratropical Northern Hemisphere and covers almost all of North America and Europe, partially extratropical North Africa and extratropical Asia. Some species can be found in the subtropics and occasionally in the tropical latitudes (Fig. 3), but mainly in the mountains, where conditions are similar to moderate or subtropical climate $[1 ; 48 ; 50]$.

9 chromosomes of the apple ancestor

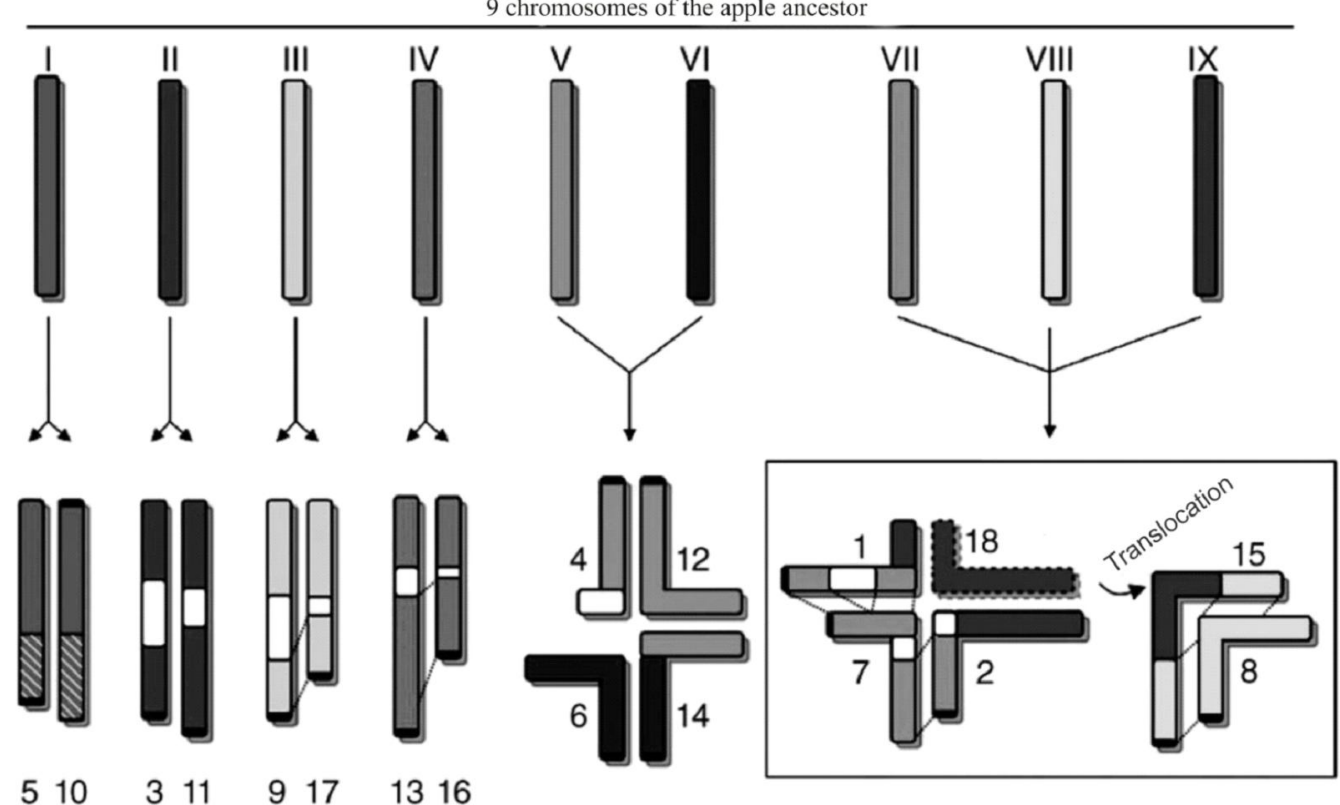

\begin{tabular}{lllll}
$510 \quad 311 \quad 917 \quad 1316$ \\
\hline 17 chromosomes of an apple-tree combined from fragments of 9 ancestral apple chromosomes
\end{tabular}

Fig. 2. The scheme of forming 17 chromosome karyotype of Malus domestica Borkh. (the scheme could be extended to other apples, including the genus Amelanchier):

the virtual chromosome 18 is shown as a source of genetic material for 1,2 and 15 apple chromosomes; white areas indicate that sequences localized at them have no ancestral prototypes

(according to R. Velasco et al., 2010 [67] as amended [46]) 


\section{БИОЛОГИЯ И БИОТЕХНОЛОГИЯ}

The analysis of the genus Amelanchier existence is defined by Armen Takhtajan (1978) biogeographic regions confirms the predominant settlement in the moderate latitudes of the Northern Hemisphere. Types of Amelanchier occur in all regions of the Boreal subkingdom, namely in Circumboreal, East Asian, Atlantic and NorthAmerican regions and the region of the Rocky Mountains; in Mediterranean and Irano-Turanian regions of the Ancient Mediterranean Subkingdom and in Madrean area of the Madrean (Sonoran) Subkingdom in Holarctic Kingdom (Fig. 4) [1; 61].
However, the vast majority of species of the genus grows within the original areal in the North America territory, from 18 to 26 [2; 29; 45]. One species is typical for Europe, Africa, and Turkey (A. ovalis) $[48 ; 50 ; 66]$. Another one occurs in Greece, on the island of Crete (A. cretica), the other - European natural hybrid of $A$. lamarckii, and 2 species grow in Turkey (A. integrifolia; A. parviflora) [48]. Two species grow in China, Korea, and Japan (A. sinica; A. asiatica) [48; 70].

The invasiveness problems of the genus Amelanchier some representatives. The

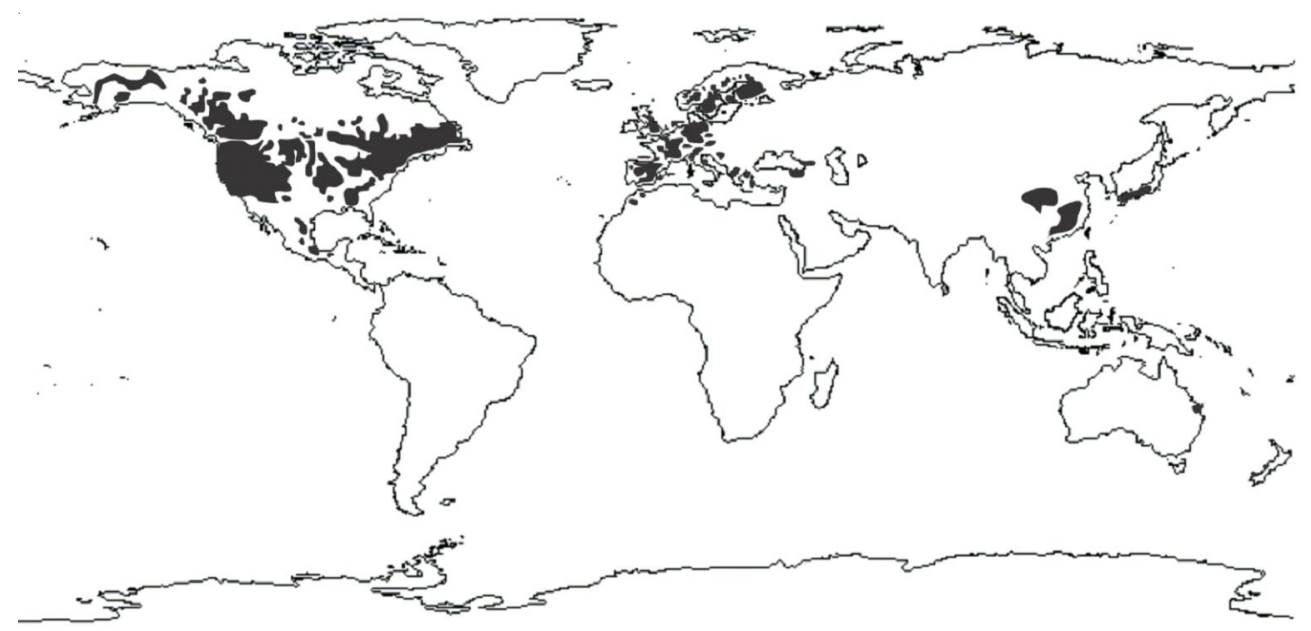

Fig. 3. The distribution of the genus Amelanchier in the world (based on site EOL (Encyclopedia of Life) [2])

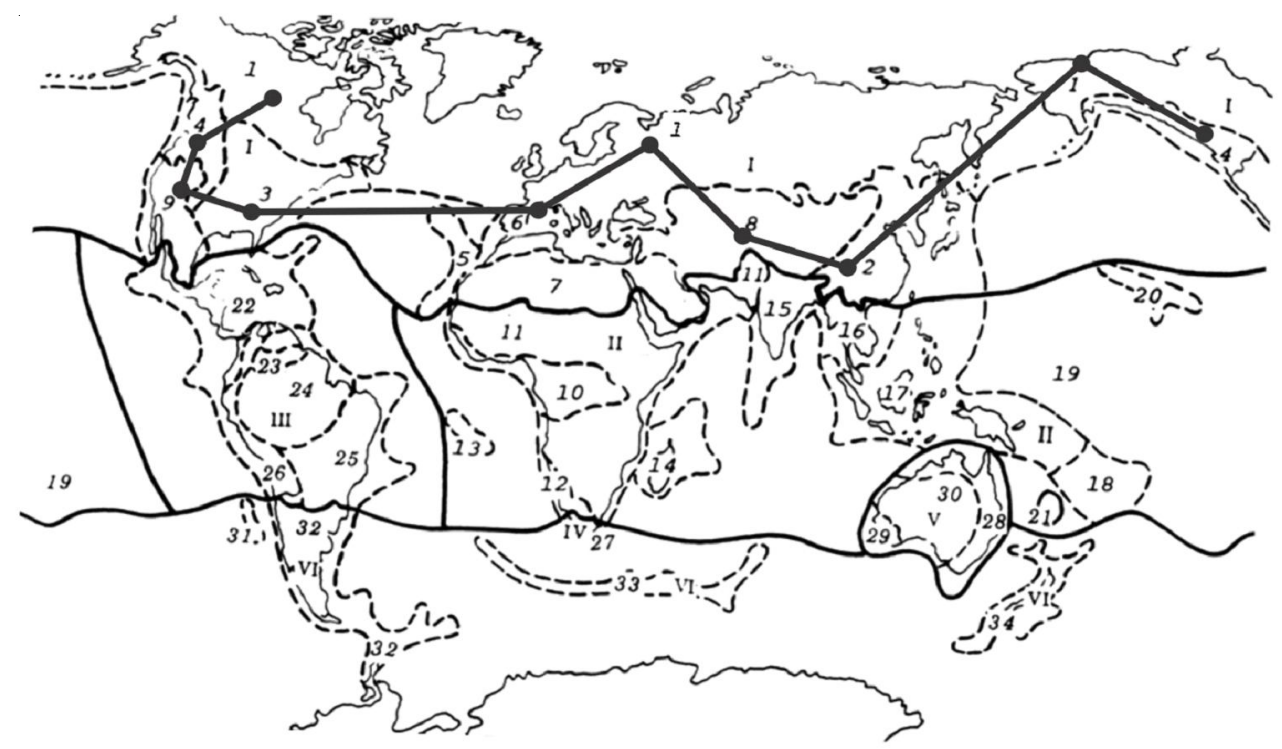

Fig. 4. The distribution of the genus Amelanchier in floristic regions defined by Armen Takhtayan (1978) [61]. The firm line defines the conventional boundaries of floristic kingdoms, dashed - areas; point (conditional core of the floristic region) at the figures shows the distribution of the genus within the regions:

1 - Circumboreal; 2 - East Asian; 3 - Atlantic, North American; 4 - Rocky Mountain region; 6 - Mediterranean; 8 - Irano-Turanian; 9 - Madrean 
genus Amelanchier representatives actively spread and are able to naturalize in natural phytocenoses of the second range. Thus, the distribution of some of them in the territory of some European countries and the European part of Russia can apply the character of phytoinvasion. The data in Table 3 show that A. spicata is characterized as the most aggressive in the European countries.

The representatives of the genus Amelanchier in the flora of Ukraine. In the flora of Ukraine, a number of the genus Amelanchier species is limited to two or three $[3 ; 52 ; 70 ; 71]$. These are $A$. ovalis, A. canadensis and A. spicata. Here with, A. ovalis is defined as an indigenous species, and $A$. canadensis and $A$. spicata are defined as introduced and naturalized in the secondary habitat. A. rotundifolia, A. integrifolia, A. oligocarpa, A. laevis, A. alnifolia, A. florida, A. utahensis, $A$. asiatica, which are unsystematically cultivated, mainly as ornamental, in private collections, botanical gardens and arboreta are referred to as a promising species for introduction, apart from A. canadensis and A. spicata.
Until recently, in the collection of the National Dendrological Park (NDP) "Sofiyivka", the genus Amelanchier was represented only by two species $A$. ovalis and A. canadensis [8].

Among the supplies of the last decade, there are representatives of the species: A. alnifolia, A. asiatica, A. canadensis, A. florida, A. laevis, A. ovalis, A. spicata, A. stolonifera, A. utahensis and A. pumila. Among them, there were plants that were delivered to "Sofiyivka" in 50-60 years of the last century, but identified only in 2004-2014, as well as new supplies from various botanical institutions. In some cases, the re-introduction of species contributed to the species specification of existing plants. Now 14 species names can be counted in the collection of the NDP "Sofiyivka". Table 4 introduced the species names of the genus Amelanchier specimens growing in the NDP "Sofiyivka", the plants of which were identified and also 28 species names, accepted in the database of Royal Botanical Gardens Kew [12].

During the time that has passed since our previous report [47], the collection of NDP "Sofiyivka"

Table 3

The invasion degree of the genus Amelanchier individual representatives in Northern and Central Europe countries and the European part of Russia, according to the materials of the website NOBANIS [14]

\begin{tabular}{|c|c|c|c|c|c|c|c|c|c|}
\hline \multirow[b]{2}{*}{ Species and the growth place } & \multicolumn{9}{|c|}{ Country } \\
\hline & $\begin{array}{l}\text { Bel- } \\
\text { gium }\end{array}$ & $\begin{array}{l}\text { Den- } \\
\text { mark }\end{array}$ & Estonia & $\begin{array}{c}\text { The } \\
\text { Euro- } \\
\text { pean } \\
\text { part of } \\
\text { Russia }\end{array}$ & Latvia & $\begin{array}{c}\text { Lithu- } \\
\text { ania }\end{array}$ & $\begin{array}{l}\text { Nor- } \\
\text { way }\end{array}$ & $\begin{array}{l}\text { Fin- } \\
\text { land }\end{array}$ & $\begin{array}{c}\text { Swe- } \\
\text { den }\end{array}$ \\
\hline $\begin{array}{l}\text { A. alnifolia } \\
\text { mixed coniferous and deciduous forests, } \\
\text { open areas, damaged areas, urban areas }\end{array}$ & - & $\mathrm{n} / \mathrm{i}$ & - & - & - & - & $\mathrm{i}$ & $\mathrm{p} / \mathrm{i}$ & $\mathrm{i}$ \\
\hline $\begin{array}{l}\text { A. canadensis } \\
\text { mixed coniferous and deciduous forests, } \\
\text { urban areas }\end{array}$ & - & - & - & $\mathrm{n} / \mathrm{i}$ & - & - & - & - & - \\
\hline $\begin{array}{l}\text { A. laevis } \\
\text { mixed coniferous and deciduous forests, } \\
\text { open areas, damaged areas, wetlands }\end{array}$ & - & - & - & - & - & - & - & $\mathrm{p} / \mathrm{i}$ & $\mathrm{n} / \mathrm{i}$ \\
\hline $\begin{array}{l}\text { A. lamarcki } \\
\text { mixed coniferous and deciduous forests, } \\
\text { open areas, damaged areas, wetlands }\end{array}$ & $\mathrm{p} / \mathrm{i}$ & $\mathrm{p} / \mathrm{i}$ & - & - & - & - & $\mathrm{i}$ & $\mathrm{p} / \mathrm{i}$ & $\mathrm{i}$ \\
\hline $\begin{array}{l}\text { A. ovalis } \\
\text { the growth place: mixed coniferous and } \\
\text { deciduous forests, urban areas }\end{array}$ & - & - & - & $\mathrm{n} / \mathrm{i}$ & - & - & $\mathrm{n} / \mathrm{i}$ & - & - \\
\hline $\begin{array}{l}\text { A. spicata } \\
\text { mixed coniferous and deciduous forests, } \\
\text { open areas, damaged areas, agricultural } \\
\text { areas, urban areas }\end{array}$ & - & $\mathrm{i}$ & $\mathrm{i}$ & $\mathrm{n} / \mathrm{i}$ & $\mathrm{i}$ & $\mathrm{i}$ & $\mathrm{i}$ & $\mathrm{i}$ & $\mathrm{i}$ \\
\hline
\end{tabular}

Note: $\mathrm{n} / \mathrm{i}$ - non-invasive; $\mathrm{p} / \mathrm{i}$ - potentially invasive; $\mathrm{i}$ - invasive; dash - no information available. 
was enlarged to 14 species. Besides, cited databases $[12 ; 64]$ in recent years became very close to the list of species names, which gave a reason to limit them to comparing the species names of the collection NDP "Sofiyivka" from the Annual checklist of Catalogue by Royal Botanical Gardens Kew.

The species $A$. alnifolia was imported from the Krivoy Rog Botanical Garden of NAS of
Ukraine. This species name was considered synonymous with $A$. sanguinea var. alnifolia (Nutt.) P. Landry in the past in the working list of known plant species The Plant List Royal Botanic Gardens, Kew and Missouri Botanical Garden, but now it is recognized as a separate species name in the above mentioned catalogue The Plant List [64], as well as in the Catalogue of Life, 2014 [12].

The genus Amelanchier collection list of the NDP "Sofiyivka" of NAS of Ukraine compared to the Catalogue of Life: 2014 Annual checklist. Catalogue by Royal Botanical Gardens Kew

\begin{tabular}{|c|c|}
\hline Catalogue of Life., 2014 [12] & Collection list of the NDP "Sofiyivka", 2014 \\
\hline A. alnifolia (Nutt.) Nutt. ex M. Roem. & A. alnifolia (Nutt.) Nutt. ex M. Roem. \\
\hline A. arborea (F. Michx.) Fernald & absent \\
\hline A. asiatica (Siebold \& Zucc.) Endl. ex Walp. & A. asiatica (Siebold \& Zucc.) Endl. ex Walp. \\
\hline A. australis Standl. & absent \\
\hline A. bakeri Greene & absent \\
\hline A. bartramiana (Tausch) M. Roem. & absent \\
\hline A. canadensis (L.) Medik. & A. canadensis (L.) Medik. \\
\hline A. covillei Standl. & absent \\
\hline A. cretica (Willd.) DC. & absent \\
\hline A. cusickii Fernald & absent \\
\hline provisionally accepted name & A. florida Wiegand \\
\hline A. grandiflora Rehder & A. grandiflora (Wiegand) Wiegand \\
\hline A. interior E.L. Nielsen & absent \\
\hline A. intermedia Spach & absent \\
\hline A. laevis Wiegand & A. laevis Wiegand \\
\hline absent & A. lamarckii F.G. Schroed. \\
\hline A. neglecta Eggl. ex G.N. Jones & absent \\
\hline A. obovalis (Michx.) Ashe & absent \\
\hline A. ovalis Medik. & A. ovalis Medik. \\
\hline A. pallida Greene & absent \\
\hline A. parviflora Boiss. & absent \\
\hline $\begin{array}{l}\text { A. pumila (Nutt. ex Torr. \& A.Gray) } \\
\text { M. Roem. }\end{array}$ & $\begin{array}{l}\text { A. pumila (Nutt. ex Torr. \& A. Gray) } \\
\text { M. Roem. }\end{array}$ \\
\hline A. quinti-martii Louis-Marie & absent \\
\hline provisionally accepted name & A. rotundifolia (Lam.) K. Koch \\
\hline A. sanguinea (Pursh) DC. & A. sanguinea (Pursh) DC. \\
\hline A. sinica (C.K. Schneid.) Chun & absent \\
\hline A. spicata (Lam.) K. Koch & A. spicata (Lam.) K. Koch \\
\hline A. stolonifera Wiegand & A. stolonifera Wiegand \\
\hline A. turkestanica Litv. & absent \\
\hline A. utahensis Koehne & A. utahensis Koehne \\
\hline
\end{tabular}


The species $A$. asiatica were delivered to the NDP "Sofiyivka" collection from O.V. Fomin Botanical Garden, Taras Shevchenko Kyiv National University research institutions in 2009. This species name is accepted in all catalogues known to us.

A. canadensis plants were first imported from Minsk Botanical Garden (now the Central Botanical Garden of NAS of Belarus) in 1959, but certainty about their species belonging was questioned after transferring plants from the domestic park arboretum to the active research and commercial arboretum, that prompted to the re-introduction of this species in 2010 from the Krivoy Rog botanical Garden. The species name is now accepted in both above mentioned databases [12; 64].

The similar story of the repeated (in 2010) introduction from the Krivoy Rog Botanical Garden of A. florida plants, representatives of which were first imported in 1959 from Leningrad Botanical Garden (now V.L. Komarov Botanical Garden of the Botanical Institute of RAS). In the Plant List [64], the name of $A$. florida Wiegand is considered unresolved, and A. florida Lindl. is synonymous with $A$. alnifolia var. semiintegrifolia (Hook.) CLHitchc., and in the Catalogue of Life... [12] A. florida Wiegand name is given as a provisionally accepted name without the name $A$. florida Lindl.

The species $A$. grandiflora, in the NDP "Sofiyivka" collection, is represented by two cultivars: 'Autumn Brilliance' and 'Forest Prince'. Its species name - Amelanchier grandiflora (Wiegand) Wiegand is now accepted in The Plant List... [64] a synonym of Amelanchier sanguinea var. grandiflora (Wiegand) Rehder., but in the same catalogue the accepted name Amelanchier $\times$ grandiflora Rehder is given. Instead, in the Catalogue of Life... [12] the accepted name $A$. grandiflora Rehder is given, whereas $A$. grandiflora Wieg. is considered a synonym for $A$. sanguinea (Pursh) DC.

A. laevis plants were first delivered in 1958 from the Botanical Garden of Uzbekistan (now the Botanical Garden of the Uzbekistan AS) and re-imported in 2010 from the Krivoy Rog Botanical Garden, which contributed to specifying the plant species. This species name is now accepted as a separate species in both above mentioned databases [12;64].
In the NDP "Sofiyivka" collection, the species A. lamarckii FG Schroed. is presented as a cultivar 'Prince William'. This species name is an accepted name in the database of The Plant List ... [64]. But in the Catalogue of Life: 2014 Annual Checklist ... [12] this species name (A. lamarckii) is removed, although in the Catalogue of Life: 2010 Annual Checklist it was given as an accepted name.

A. ovalis plants are classified as representatives of the long and widely spread species (in all parts of "Sofiyivka") by the NDP "Sofiyivka" catalogue in 2000 [8]. This name is accepted by both the above mentioned catalogues $[12 ; 64]$.

The species name $A$. pumila (Nutt. ex Torr. \& A.Gray) M.Roem. is now accepted in both above mentioned databases $[12 ; 64]$.

The species name $A$. rotundifolia (Lam.) K. Koch, plants of which were imported from Kaunas Botanical Garden (now the Vytautas the Great University Botanical Garden) in 1958, is included in The Plant List ... [64] as an unresolved name, and in the Catalogue of Life... [12] is considered as a synonym for A. ovalis subsp. ovalis Medik.

Re-introduction (in 2010) from the Krivoy Rog Botanical Garden of A. sanguinea (Pursh) DC. plants, representatives of which were first imported from Leningrad Botanical Garden (now V.L. Komarov Botanical Garden of the Botanical Institute of RAS) in 1958, was contributed to specifying species belonging of existing plants. The species name is accepted by both the above mentioned catalogues, which gives grounds for certainty in its status $[12 ; 64]$.

A. spicata as well as A. ovalis are classified by NDP "Sofiyivka" Catalogue of 2000 as a long spread species in all parts of the park [8]. However, the features of vegetative and generative organs variations, which are referred to this species plants, prompts for further more grounded analysis. Therefore, A. spicata representatives delivered from the Krivoy Rog Botanical Garden in 2010 were planted in the the NDP "Sofiyivka" collection to compare and specify the status of the existing plants under this plant name. In the Plant List... [64] A. spicata is accepted as a species name. But in the Catalogue of Life... [12] A. spicata is considered as a synonym for A. canadensis (L.) Medik. 
The plants A. stolonifera and A. utahensis, imported from the Krivoy Rog Botanical Garden in 2010, belong to new supplies of the genus Amelanchier specimens. Thus, in the Plant List... [64] and in the Catalogue of Life... [12] are both accepted species names.

The similar divergences in approaches to systematize species names and specify the composition the genus are observed when comparing the names of other Amelanchier species, so far absent in NDP "Sofiyivka" of NAS of Ukraine collection, but available in other catalogues $[12 ; 64]$. The desired consensus can be achieved by combining the results of the species identification by classical (morphological) and molecular genetic criteria. Today, collecting new genotypes of the genus Amelanchier continues, and exploring new supplies has already started.

In addition to the above-mentioned species of Amelanchier in the NDP "Sofiyivka" collection, a number of cultivars are researched, seedlings of which are grown from in vitro propagated plants: 'Autumn Brilliance', 'Forest Prince', 'Krasnojarskaja', 'Pembina', 'Prince William', 'Slate', 'Snowcloud', 'Smoky', including old cultivars: 'Pembina', 'Smoky'.

The analysis of differences in species names and common names of the genus Amelanchier specimens in some well-known websites [12; 64], demonstrates the need for their further arranging. However, as a great advantage of these $[12 ; 64]$ and other similar electronic databases of plant species names, one should accept their general availability, ease of use and, what is very important, is a constant dynamism, the ability to collect and analyze new information and arrange it.

\section{Conclusion}

Thus, in Ukraine, the representatives of the genus Amelanchier are still unconventional plants for the culture, but interest in them is constantly growing, due to their fruit ornamental value, nectareous, medicinal phytomeliorative abilities.

The results of the phylogenetic and molecular genetic studies performed by scientists from different countries give an opportunity to specify the systematic position of the representatives of the genus Amelanchier of the family Rosaceae Juss. grown in Ukraine, and temporarily place them in a large subfamily Amygdaloideae Arn., which unites the former subfamilies Amygdaloideae, Spiraeoideae and Maloideae, tribe - Maleae Small, subtribe - Malinae Rev.

The divergences in species and interspecies classification of the genus Amelanchier representatives found in various publications indicate incompleteness of the genus system and necessity for further studies by classical and molecular genetic methods.

\section{Acknowledgement}

This material is partly based on the work supported by the National dendrological park "Sofiyivka" of NAS of Ukraine (№ 0112U002032) together with Uman National University of Horticulture (№ 0101U004495) in compliance with their thematic plans of the research work. We thank corresponding members of NAS of Ukraine Ivan Kosenko and Ph.D. Galyna Chorna for consultations and discussion.

\section{REFERENCES}

1. Aldasoro J.J., Aedo C., Navarro C. Phylogenetic and Phytogeographical Relationships in Maloideae (Rosaceae) Based on Morphological and Anatomical Characters. Blumea, 2005, vol. 50, no. 1, pp. 3-32.

2. Amelanchier (Shadbush). Maps. Available at: http://eol.org/pages/29970/maps (accessed May 19, 2014).

3. Andrienko N.V., Roman I.S. Irha. Maloposhyreni yahidni i plodovi kultury [Juneberry. Rare Berry and Fruit Crops]. Kyiv, Urozhai Publ., 1991, pp. 79-84, 153-154. (in Ukrainian).

4. Annenkov N.I. Amelanchier Med. Botanicheskiy slovar [Amelanchier Med. Botanical Dictionary]. Saint Petersburg, Imperial Academy of Sciences, 1878, pp. 27-28. (in Russian).

5. Antsiferov A. Irga - medovoe vino [Juneberry Is Honey Wine]. Neskuchnyy sad, 2011, no. 6 (65), pp. 44-47. (in Russian).

6. An Update of the Angiosperm Phylogeny Group Classification for the Orders and Families of Flowering Plants: APG III. The Angiosperm Phylogeny Group. Botanical Journal of the Linnean Society, 2009, vol. 161, pp. 105-121.

7. Axelrod D.I. Evolution of the Madro-Tertiary Geoflora. Botanical Review, 1958, vol. 24, no. 7, pp. 433-509.

8. Bilyk O.V., Vegera L.V., Dzhym M.M., et al. Kataloh Roslyn dendrolohichnoho parku 
"Sofiyivka" [Catalogue of the Sofiyivka Dendrological Park Plants]. Uman, 2000. 94 p. (in Ukrainian).

9. Burmistrov A.D. Irga. Yagodnye kultury [Juneberry. Berry Crops]. Leningrad, Agropromizdat Publ., 1985, pp. 240-245. (in Russian).

10. Campbell C.S., Evans R.C., Morgan D.R., et al. Phylogeny of Subtribe Pyrinae (Formerly the Maloideae, Rosaceae): Limited Resolution of a Complex Evolutionary History. Plant Systematics and Evolution, 2007, vol. 266, no. 1-2, pp. 119-145.

11. Campbell C.S., Wright W.A. Apomixis, Hybridization, and Taxonomic Complexity in Eastern North American Amelanchier (Rosaceae). Folia Geobotanica and Phytotaxonomica, 1996, vol. 31, no 3, pp. 345-354.

12. Catalogue of Life: 2014 Annual Checklist. Catalogue by Royal Botanical Gardens Kew. Available at: http://www.catalogueoflife.org/annualchecklist/2014/search/all/key/Amelanchier/match/1 (accessed May 8, 2014).

13. Chernik V.V., Dzhus M.A., Sautkina T.A., et al. Sistematika vysshikh rasteniy. Pokrytosemennye. Klass Dvudolnye [The Systematics of Higher Plants. Angiosperms. Dicotyledonous Class]. Minsk, Belarus State University Press, 2010, pp. 203-212. (in Russian).

14. Country Statistics. European Network on Invasive Alien Species (NOBANIS). Gateway to Information on Alien and Invasive Species in North and Central Europe. Available at: http://www.nobanis. org/Search.asp (accessed May 20, 2014).

15. Darlington C.D., Moffett A.A. Primary and Secondary Chromosome Balance in Pyrus. Journal of Genetics, 1930, vol. 22, no. 2, pp. 129-151.

16. Dickinson T.A., Lo E.Y.Y., Talent N. Polyploidy, Reproductive Biology, and Rosaceae: Understanding Evolution and Making Classifications. Plant systematics and evolution, 2007, vol. 266, no. 1-2, pp. 59-78.

17. Dickson E.E., Arumuganathan K., Kresovich S., et al. Nuclear DNA Content Variation Within the Rosaceae. American journal of botany, 1992, vol. 79, no. 9, pp. 1081-1086.

18. Dobrochaeva D.N., Kotov M.I., Prokudin Y.N., et al. Rod 13. Irga (Irga) - Amelanchier Medik. Opredelitel vysshikh rasteniy Ukrainy [Genus 13. Saskatoon (Juneberry) - Amelanchier Medik. Determinant of Higher Plants of Ukraine]. Kyiv, Naukova Dumka, 1987, pp. 159-160. (in Russian).

19. Engler A. Syllabus der Pflanzenfamilien. Eine ábersicht áber das gesamte Pflanzensystem mit Berócksichtigung der Medicinal- und Nutzpflanzen nebst einer bbersieht óber die Florenreiehe und Florengebiete der Erde zum Gebrauch bei Vorlesungen und Studien óber specielle und medicinisch-pharraaceutische Botanik. Berlin, Verlag von Gebróder Borntraeger, 1903. 233 p.
20. Evans R.C., Alice L. A., Campbell C.S., et al. The Granule-Bound Starch Synthase (GBSSI) Gene in the Rosaceae: Multiple Loci and Phylogenetic Utility. Molecular phylogenetics and evolution, 2000, vol. 17, no. 3, pp. 388-400.

21. Evans R.C., Campbell C.S. The Origin of the Apple Subfamily (Maloideae; Rosaceae) Is Clarified by DNA Sequence Data From Duplicated GBSSI Genes. American journal of botany, 2002, vol. 89, no. 9, pp. 1478-1484.

22. Evans R.C., Dickinson T.A. Floral Ontogeny and Morphology in Gillenia ("Spiraeoideae") and Subfamily Maloideae C. Weber (Rosaceae). International Journal of Plant Science, 2005, vol. 166, no. 3, pp. 427-447.

23. Gladkova V.N. Poryadok rozovye, ili rozocvetnye (Rosales). Zhizn rasteniy. V. $6 t$. [Pink, or Rose Family Order (Rosales). Plant Life. In 6 vols]. Moscow, 1980, vol. 5/2, pp. 175-189. (in Russian).

24. Glukhov A.A. Medonosnye rasteniya [Nectareous Plants]. Moscow, State Publishing House of Agricultural Literature, 1955. 512 p. (in Russian).

25. Grysyuk M.M., Yellin Yu.Ya. Dykorosli kharchovi, tekhnichni i medonosni roslyny Ukrayiny [Wild Food, Technical and Nectareous Plants of Ukraine]. Kyiv, Urozhai, 1993. 208 p. (in Ukrainian).

26. Haston E., Richardson J.E., Stevens P.F., et al. The Linear Angiosperm Phylogeny Group (LAPG) III: a Linear Sequence of the Families in APG III. Botanical Journal of the Linnean Society, 2009, vol. 161 , no. 2, pp. 128-131.

27. International Code of Nomenclature for Algae, Fungi, and Plants (Melbourne Code) Adopted by the Eighteenth International Botanical Congress, Melbourne, Australia, July 2011. Section 2. Names of Families and Subfamilies, Tribes and Subtribes. Chapter III. Nomenclature of Taxa According to Their Rank. Article 19. Available at: http://www.iapttaxon.org/nomen/main.php?page=art19 (accessed May 12, 2014).

28. Janick J., Cummins J.N., Brown S.K., Hemmat M. Apples. Fruit Breed. Vol. 1: Tree and Tropical Fruits. New York, John Wiley and Sons, 1996, pp. 1-78.

29. Jones G.N. American Species of Amelanchier. Illinois Biological Monographs, 1946, vol. 20, no 2, pp. $1-126$ p.

30. Kaden N.N., Terentyeva N.M. Etimologicheskiy slovar latinskikh nazvaniy rasteniy, vstrechayushchikhsya $v$ okrestnostyakh agrobiostantsii MGU "Chashnikovo" [Etymological Dictionary of the Latin Names for Plants Found in the Chashnikovo Agrobiological Station of Moscow State University]. Moscow, Lomonosov Moscow State University Press, 1975. 203 p. (in Russian).

31. Kobiv Y. Slovnyk ukrayinskykh naukovykh $i$ narodnykh nazv sudynnykh Roslyn [Dictionary of 
Ukrainian Scientific and Vernacular Names for Plants]. Kyiv, Naukova Dumka, 2004. 800 p. (in Ukrainian).

32. KosenkoI.S., Khraban G.Y., Mitin V.V., Garbuz V.F. Dendrologichnyy park "Sofiyivka": 200 rokiv [Sofiyivka Dendrological park: 200 years]. Kyiv, Naukova Dumka, 1996, pp. 165-180. (in Ukrainian).

33. Kuklina A.G. Naturalizatsiya severoamerikanskikh vidov irgi (Amelanchier Medik.) vo vtorichnom areale [Naturalization of Amelanchier Species From North America in a Secondary Habitat]. Russian Journal of Biological Invasions, 2011, vol. 2, no. 2-3, pp. 103-107. (in Russian).

34. Kuklina A.G. Zhimolost, irga: Posobie dlya sadovodov lyubiteley [Honeysuckle, Juneberry: A Manual for Amateur Gardeners]. Moscow, Niola Press, 2007. 240 p. (in Russian).

35. Landry P. Le Concept D'espece et la Taxonomie du Genre Amelanchier (Rosacees) [On the Concept of Species and the Taxonomy of Genus Amelanchier (Rosaceae)]. Bulletin de la Sociütŭ Botanique de France, 1975, vol. 122, no. 5-6, pp. 243-252.

36. Lim T.K. Amelanchier Alnifolia. Edible Medicinal and Non-Medicinal Plants. Dordrecht; Heidelberg; London; New York, Springer, 2012, vol. 4, pp. 358-363.

37. Linnaei C. Chionanthus. Species Plantarum, Exhibentes Plantas Rite Cognitas, Ad Genera Relatas, Cum Differentiis Specificis, Nominibus Trivialibus, Synonymis Selectis, Locis Natalibus, Secundum Systema Sexuale Digestas. Holmiae, Laurentii Salvii, 1753, vol. 1, pp. 479-480.

38. Lukin V.D. Luchshie prutya dlya podelok iz irgi [Best Bars for Handicrafts From Juneberry]. Orchard and garden, 2006, no. 8 (89), pp. 30-30 (in Russian).

39. Markovskyi V.S., Bakhmat M.I. Irha. Yahidni kultury v Ukrayini [Juneberry. Berries in Ukraine]. Kamenetz-Podolskiy, Medobory-2006, 2008, pp. 166168 (in Ukrainian).

40. Matthias de l'Obel. Amelanchier. Kruydtboeck Oft Beschryuinghe Van Allerleye Ghewassen, Kruyderen, Hesteren, Ende Gheboomten. Plantyn Ch., ed. T'Antwerpen, 1581, p. 223.

41. Medicus F.C. Amelanchier. Philosophische Botanik: mit kritischen Bemerkungen [Amelanchier. Philosophical Botany: With Critical Remarks]. Von den mannigfaltigen Umhüllungen der Saamen. Mannheim, 1789, vol. 1, pp. 135-135.

42. Mosyakin S.L., Fedoronchuk M.M. Vascular Plants of Ukraine: a Nomenclatural Checklist. Kiev, National Academy of Sciences of Ukraine, 1999. $286 \mathrm{p}$.

43. Nekrasov S.A. Irga. Yagodnyy sad [Juneberry. Berry Garden]. Minsk, MET Ltd. 2001, pp. 222-228. (in Russian).

44. Opalko A.I., Zaplichko F.O. Selektsiya zernyatkovykh kultur. Selektsiya plodovykh $i$ ovoshchevykh kultur [Pome Fruit Crops Breeding. Fruit and Vegetable Crops Breeding]. Kyiv, Higher School, 2000, pp. 345-385. (in Ukrainian).

45. Opalko A.I., Andrienko O.D., Opalko O.A. Dyskusiyni pytannya systemy rodu Amelanchier Medik. [Disputable Issues of the Genus Amelanchier Medik. Taxonomy]. Fruit, Medicinal, Industrial, Ornamental Plants: Current Issues of Introduction, Biology, Breeding, Cultivation Technology. In the Memory of Distinguished Scientist, Academician N.F. Kaschenko and to the $100^{\text {th }}$ Anniversary of the Foundation of Acclimatization Garden (Proceedings of the International Scientific and Practical Distant Conference, September 4, 2014, Kyiv, Ukraine). Kyiv, 2014, pp. 191-195 (in Ukrainian).

46. Opalko A.I., Kucher N.M., Opalko O.A., Chernenko A.D. Filohenez i fitoheohrafiya zernyatkovykh plodovykh kultur [Phylogeny and Phytogeography of Pome Fruits]. Avtokhtonni ta introdukovani roslyny. Zbirnyk naukovykh pracy Nacionalynogho dendroparku "Sofiyivka" UkrajinyAutochthonous and alien plants [The Collection of Proceedings of the Sofiyivka National Dendrological Park of NAS of Ukraine]. 2012, vol. 8, pp. 35-44. (in Ukrainian).

47. Opalko A.I., Andrienko O.D., Opalko O.A. Predstavnyky Amelanchier Medik. u NDP "Sofiyivka" NAN Ukrayiny [Amelanchier Medik. at the Sofiyivka National Dendrological Park of NAS of Ukraine]. Visti Biosfernogho zapovidnyka "Askaniya Nova" (Specvypusk), 2012, vol. 14, pp. 194-198 (in Ukrainian). 48. Phipps J.B., Robertson K.R., Smith P.G., Rohrer J.R. A Checklist of the Subfamily Maloideae (Rosaceae). Canadian journal of botany, 1990, vol. 68 , no. 10 , pp. 2209-2269.

49. Potter D., Eriksson T., Evans R.C., et al. Phylogeny and Classification of Rosaceae. Plant systematics and evolution, 2007, vol. 266, no. 1-2, pp. 5-43.

50. Poyarkova A.I. Rod 730. Irga-Amelanchier Medik. Flora SSSR. V 30 t. [Genus 730. JuneberryAmelanchier Medik. Flora of the USSR. In 30 vols]. Moscow-Leningrad, USSR Academy of Sciences Publishing House, 1939, vol. 9, pp. 408-413 (in Russian).

51. Rehder A. New Species, Varieties and Combinations From the Herbarium and the Collections of the Arnold Arboretum. Journal of the Arnold Arboretum, 1920, vol. 1, no. 4, pp. 254-263.

52. Ryazanova O.A. Novaya sadovaya kultura [New Garden Culture]. Sadovodstvo i vinogradarstvo, 1999, no. 3, pp. 23-24 (in Russian).

53. Sautkin F.V. Struktura kompleksa fitofagovvrediteley irgi (Amelanchier spp.) v usloviyakh Belarusi [Complex Structure of Phytophagans Juneberry (Amelanchier spp.) Pests in the Climatic Conditions of Belarus]. Vestnik Belorusskogo 
gosudarstvennogo universiteta, 2012, ser. 2, no. 2, pp. 38-42 (in Russian).

54. Sax K. The Origin and Relationships of Pomoideae. Journal of the Arnold Arboretum, 1931, vol. 12, no. 1, pp. 3-22.

55. Schuster M., Bьttner R. Chromosome Numbers in the Malus Wild Species Collection of the Genebank Dresden-Pillnitz. Genetic Resources and Crop Evolution, 1995, vol. 42, no. 4, pp. 353-361.

56. Shabarova S.I., Tarhonskiy P.N. Rid IrgaAmelanchier. Plodovye, yagodnye $i$ orehoplodnye rastenija lesov SSSR [Juneberry Genus - Amelanchier. Fruit, Berry and Nut Plants of the USSR forests]. Kyiv, Higher School, 1984, pp. 47-48 (in Ukrainian).

57. Shukel I.V., Dyda A.P., Nizhalovskiy Y.V. Vykorystannya Amelanchier ovalis Medik v rekreatsiyniy fitomelioratsiyi [Using Amelanchier Ovalis Medik in the Recreational Phytomelioration]. Naukovyy visnyk Ukrainskogho derzhavnogho lisotekhnichnogho universytetu, 2003, iss. 13.5, pp. 379-383 (in Ukrainian).

58. St-Pierre R.G. Growing Saskatoons. A Manual for Orchardists. Department of Horticulture Sciences, University of Saskatchewan. Saskatoon, SK, 1997. 338 p.

59. Timonin A.K., Sokolov D.D., Shipunov A.B. Ordo Rosales - poryadok rozocvetnye. Botanika. V 4 t. T. 4. [Ordo Rosales - Rosales Order. Botany. In 4 vols. Vol. 4. The Systematics of Higher Plants]. Moscow, Academy Publishing Center, 2009, pp. 239-241.

60. Takhtayan A.L. Sistema i filogeniya tsvetkovykh rasteniy [The Systema and the Phylogenia of Magnoliophytorum]. Moscow-Leningrad, Nauka Publ., 1966. 612 p. (in Russian).

61. Takhtayan A.L. Floristic Regions of the World. Berkeley, University of California Press, 1986. $544 \mathrm{p}$.

62. Takhtayan A.L. Flowering Plants. $2^{\text {nd }}$ ed. New York, Springer Science + Business Media, 2009. 871 p.
63. Talent N., Dickinson T.A. Polyploidy in Crataegus and Mespilus (Rosaceae, Maloideae): Evolutionary Inferences From Flow Cytometry of Nuclear DNA Amounts. Canadian Journal of Botany, 2005, vol. 83, no. 10, pp. 1268-1304.

64. The Plant List by the Royal Botanic Gardens Kew and Missouri Botanical. 2013. Available at: http: //www.theplantlist.org/tpl1.1/search?q=Amelanchier (accessed May 12, 2014).

65. Tournefort J.P. Genus II. Mefpilus Neflier. Institutiones Rei Herbarię. Parisiis, E Typographia Regia, 1700, vol. 1, pp. 641-642.

66. Tzvelev N.N. Rod 34. Irga-Amelanchier Medik. Flora Vostochnoy Evropy [Genus 34. Juneberry-Amelanchier Medik. The Flora of Eastern Europe]. Saint Petersburg, World and Family, 2001, vol. 10, pp. 552-555 (in Russian).

67. Velasco R., Zharkikh A., Affourtit J., et al. The Genome of the Domesticated Apple (Malus Domestica Borkh). Nature Genetics, 2010, vol. 42, no. 10, pp. 833-839.

68. Weber C. The Genus Chaenomeles (Rosaceae). Journal of the Arnold Arboretum, 1964, vol. 45, no. 2, pp. 161-205; no. 3, pp. 302-345; 2003, pp. 190-190.

69. Wolfe J.A., Wehr W.C. Rosaceous Chamaebatiaria-LikeFoliage From the Paleogene of Western North America. Aliso, 1988, vol. 12, no. 1, pp. 177-200.

70. Wu Z., Raven P.H., Hong D., et al. 24. Amelanchier Medikus. Flora of China. Vol. 9: Pittosporaceae Through Connaraceae. Missouri Botanical Garden Press

71. Zatylny A.M., St-Pierre R.G. Revised International Registry of Cultivars and Germplasm of the Genus Amelanchier. Small Fruits Review, 2003, vol. 2, no. 1, pp. 51-80.

72. Zielinski Q.B., Thompson M.M. Speciation in Pyrus: Chromosome Number and Meiotic Behavior. Botanical gazette, 1967, vol. 128, no. 2, pp. 109-112.

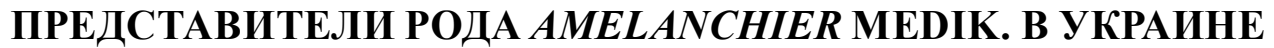

\section{Опалко Анатолий Иванович}

Кандидат сельскохозяйственных наук, профессор, заведующий отделом физиологии, генетики, селекции и биотехнологии, Национальный дендрологический парк «Софиевка» НАН Украины opalko_a@ukr.net ул. Киевская, 12-а, 20300 г. Умань, Украина

\section{Андриенко Елена Дмитриевна}

Преподаватель кафедры биологии и методики ее преподавания, Уманский государственный педагогический университет им. Павла Тычины olena_andrienko@ukr.net ул. Садовая, 2, 20300 г. Умань, Украина 


\section{Опалко Ольга Анатолиевна}

Кандидат сельскохозяйственных наук, доцент, старший научный сотрудник, Национальный дендрологический парк «Софиевка» НАН Украины, отдел физиологии, генетики, селекции и биотехнологии opalko_o@ukr.net ул. Киевская, 12-а, 20300 г. Умань, Украина

Аннотация. Обобщена информация, касающаяся плодово-декоративной ценности, медоносных и лекарственных свойств ирги (представителей рода Amelanchier Medik.). Характеризуются их биологические особенности, химический состав и вкусовые качества, способы употребления и переработки плодов, в частности сушки, изготовления сока, сиропа, джема, мармелада и конфитюра, фруктового вина. Освещены направления эволюции, природный ареал, экологическая адаптивность и эффективность использования ирги для фитомелиорации, а также угрозы, касающиеся возможной инвазийности некоторых представителей этого рода. Рассмотрены отдельные версии происхождения названия рода Amelanchier и толкование его видовых эпитетов в разных странах мира. Анализируются дискуссионные вопросы системы рода Amelanchier исходя из классических и молекулярно-генетических позиций. Обсуждается роль интродукции для расширения коллекционного фонда и повторной интродукции для уточнения видовой принадлежности ранее интродуцированных в Национальный дендрологический парк «Софиевка» НАН Украины представителей рода Amelanchier.

Ключевые слова: ареал, биоразнообразие, число хромосом, ДНК-последовательность, семейство, флористическая область, ирга, фитомелиоративный, таксономия, триба. 